\title{
The Reproduction of Political Power in The Institutions of Village (1979-1999) and Nagari (2000- 2015) in West Sumatera
}

\author{
Tengku Rika Valentina ${ }^{1}$, Roni Ekha Putera ${ }^{2}$ Irawati $^{3}$ \\ Irawati $^{2}$ \\ $\left\{\right.$ tengkurika@soc.unand.ac.id ${ }^{1}$, roniekhaputera@soc.unand.ac.id ${ }^{2}$,
}

Department of Political Science, Faculty of Social and Political Sciences, Universitas Andalas, Padang, Indonesia ${ }^{1,3}$, Department of Public Administration, Faculty of Social and Political Sciences, Universitas Andalas, Padang, Indonesia ${ }^{2}$

\begin{abstract}
The political policy is taken by the West Sumatera Regional Government, i.e., the overhauling of the institutional structure of Nagarirationally turns out to have been culturally constructed since the bureaucratic system changed from the village government to the Nagari government. What appears to be the stability of political institution in the regions, one of which is Nagari, turns out to be the intervention of central government in the implementation of autonomy and decentralization. Using the explorative post-positive method, the study aims to produce a conceptually and variably solid analysis in the form of descriptive writing. The result of this study shows that there is an institutional problem when the state (central and provincial government) underrates the Nagari, emphasizing merely on regional autonomy for the interests of the central government. There is the process of habitus, social capital, the political arena, and doxa that affect local institutions in Nagari when it is imposed to become part of the state political power reproduction. There are also several actions of some actors at the local and central level to take a role in democratizing the Nagari.
\end{abstract}

Keywords: Habit, Social Capital, Arena, Doxa, Democracy, Nagari.

\section{Introduction}

The local political setting in Nagari community has some bearing on the problematic existence of local institutions and wisdom that had once been famous before the treatment and uniformity of the village law in 1975 (Law No. 5 of 1979 on the Village); there is an apparent irony, an attempt to keep the 'balance function' between the regional government and the village or Nagari. In such connotation, Nagari is a community of customary law that is socio-politically not only entitled, but also capable of organizing and managing its interests. Here Nagari is relatively more independent and less burdened by state interests (central and provincial governments). Nevertheless, Nagari is required to be part of the modern government bureaucratic chain. The study on how the structures, rules, norms, and political institutions worked as part of the democratization process in Nagari from 1979 to 2015 contributes novelty to and strengthens the study on the habitus of democracy at the local level. The underlying reason is that efforts toward 'grassroots democracy' will presuppose the existence of social institutions at the local level. When democracy is an important part of the political institution, 
then institutionalization of democracy into an autonomous institution shall ensure the continuity of the process of habitus making of democratization, and become an interesting point to examine.

\section{Method}

This study applies the explorative post-positive method to generate varied and conceptual solid analysis to portray descriptive writing (Denzin and Lincoln, 2009, p. 351). The data source comes from primary data (in-depth interviews with the relevant parties) and secondary data (files, personal documents, official documents, and scientific magazines). Data analysis is adapted to the principles of post-positive explorative method. The conclusion of the study is obtained from the combination of data given by the informants (emic) and interpretation of the author (ethic) on the data.

\section{Results and Discussion}

Observing the political institutions of village (1979-1999) and Nagari (2000-2015) based on the structure, rules, norms and culture,this study applies the concepts developed by Bourdieu (1986)such as habitus, social capital, arena, and doxato explain the influence of local institutions in Nagari when they become part of the democratization process. Thus, how is the relationship between arena, habitus, social capital, and doxa in the local democratization process in Nagari? The history and heritage of Nagari and Nagari government is a political arena used as the social capital long known, with the oldest Nagari ofPariangan in Luhak Tanah Datar. Based on the history of Nagari, as suggested by Imran Manan (2003, p.4) in his writing entitled "Nagari PraKolonial: Historiografi Nagari", the development of Nagari is illustrated based on Minangkabau ancient manuscripts (tambo). These Nagaris will form a federation of Nagari whose governance and political traditions were based on the traditional customs of kelarasankotopiliang (aristocracy) and bodichaniago (egalitarian).

Political history of Nagari is divided into several stages, e.i (i) Nagari government originated from clan government; (ii) during pre-colonial era after the introduction of Islam in Minangkabau, known as political government system of twokelarasan (Koto Piliang and BodiChaniago) with the democracy of TuahSakato; (iii) during the colonial era, the institutions of the Nagari government began to experience a shift in function when the Dutch tried to paralyze the power of Ninik Mamak Urang Ampek Jinih (Dubalang, Punggawa, Manti, Malin) in the Nagari government; (iv) After the independence of Indonesia, during the Old Order period, the Nagari government was replaced by a regional government system with a merging system of adjacentNagaris to create an autonomous Nagari based on the Provincial Regulation of Central Sumatra No. 50.G.P/1950; (v) during the New Order period, there was a uniformity of the lowest government from Nagari to village government and the Nagari government was established as an adat government; (vi) during the Reform era, the village government was abolished and Nagari was re-formulated to be the lowest governmental structure, the people of Nagari made as adat community with their characteristics of governance, and the state respected these differences by issuing Law no. 22/1999 as amended by Law No. 32/2004 on Regional Government, and Local Regulation No. 9/2000 as amended byRegional GovernmentNo. 2/2007 on Nagari. 
What the pattern of the political structure of village government (1979-1999) and Nagari government (2000-2015)? The author refers to Islam, adat, and the State as the structured institutional structures in Nagari. The relationship between adat and Islam, and later between adat, Islam, and the state also varies in history (von Benda-Beckmann 2000). According to von Benda-Beckmann (2000); the duality of adat and Islam remains one of the central and constitutive points of identification for most local elites in Minangkabau when re-formulating the arena of Nagari. Interestingly, this series of historical processes have eventually generated a new habitus within the social structure and arena of the community.

Referring to the concept by Bourdieu (1990), Islam, adat, and state are structured structures (habitus). The policy of inauguration of Nagari as a unit of adat community in Minangkabau based on the Regional Regulation No. 13/1983 can be regarded as an attempt to reduce crises of traditional leadership and maintain the social and cultural unity of Muslim-based Nagari community. Transforming Nagari into an adat and Islamic government is culturally considered as a symbol of the unity of adat community and the origin of life and culture in Minangkabau, referred to as the product of the internalization of the structure of the social world. The structure of social value is manifested in the form of Minangkabau norms and values. During the development, the internalization process begins to grow. It is said to be a new habit, in which Nagari does not only perform the function of regulating the unity of adat community but also become part of the informal government accompanying village (formal)government.

The habit in Nagari government is slightly different after the village government is back to Nagari government (2000-2015). The political policy of the local government Nagari is managed by a cultural regulator, Nagari Customary Unit (KAN), as the judicial partner of Nagari government and reinforce the function of the Nagari government as a formal institution as well as the three-parties (Tungku Tigo Sajarangan Nagari) between Nagari Board of Representatives (BMN) as a legislative body and Nagari Customary Unity (KAN) as the judicial institution of Nagari(internalization of externality) by constituting the cultural values and norms of adat salingka Nagari based on adat and Islam. This process becomes a new habit in Nagari.

Where is the legitimacy of political doxa in Nagari? In this section, the concept of legitimacy in Minangkabau society is explained. This legitimacy refers to the concept of doxa by Bourdieu (1990, p.68), namely something accepted and recognized (taken for granted)by the community. A group of people gives this legitimacy to individuals in the political sphere. Penghulu/Datuak, BundoKanduang, AlimUlama, CerdikPandai are referred to as doxa in social political life in Minangkabau. It is the custom and even conviction that those having customary title will be the protectors and role models in the clan; overall, they can explain social action in the political tradition in Nagari. The first Doxa is Penghulu/Datuk (NinikMamak), namely the chief of the clan (biangtabuak, katoputuih ado panghulu). Penghulu is the one setting and deciding nan rajokatomufakaik(decisions taken and agreed by all the members of the clan). In addition, Penghulu is a part of tungkutigosajarangan, namely anggo-anggo, considered as the basic and adat household budget. BundoKanduang is the second doxa considered as ambunpuruakpeggangankunci. It is a symbol of Minangkabau women who understand adat andbecome the adviser of penghulu regarding all the decisions of the meeting. The third doxa, related to sharia (religion), is titledTuangku/Malin/Labai/Kari. The last doxa is given to smart (intelligent) individuals in the clanor cadiakpandai, including handy and skillful youth/hulubalang, commonly known as UrangAmpekJinih (UAJ).NinikMamak, AlimUlamaand CadiakPandai are doxa in Minangkabau known as TaliTigoSapilin, meaning the three functions in adat become one individual of "minang".

Closing the explanation on the pattern of reproduction of political power in the village (1979-1999) and Nagari (2000-2015) in West Sumatra, the overall implementation of the 
legitimacy of the community built on political culture (adat, religion) and the network as political strategy are basically included in doxa. It is emphasized that the reproduction of power grow from social capital;it roots deep in the habitus of the community bound in doxa. At this point, some titled members of the clan have succeeded in using their powers in village and Nagari government.

Where is the extra political arena in the democracy in Nagari? It is located in the management of the clan (suku). Based on the analysis, clan management is an effort initiated by the people of West Sumatra and the diaspora to revive the customary laws by rewriting them. Each Minangkabau person will live by his clan; there is a maxim "suku bersatu kaki, satu kaki adalah seperempat bagian (the clan is united in one leg, one which is of four quarter parts)."It means four quarter parts of four parent-clans, namely: Koto, Piliang, Bodi, and Chaniagoas established by Datuak Katumangguangan and Datuak Perpatih Nan Sabatang. This clan division greatly influences the composition of the Minangkabau community. The maxim goes: "people of the similar clan have a strong sense of unity and solidarity, and each clan member feels responsible for what his tribe members are doing."

\section{Conclusion}

The change of governance towards a decentralized style as stipulated in Law no. 22/1999 as amended by Law no. 32/2004 on Regional Government cannot be separated from the public attitude and response against the repressive actions conducted by the New Order government. The implementation of the wheels of local government at that period was influenced more by the intervention of the central government rather than the initiative of the regional government. The shift in the implementation of local government that emphasizes direct autonomy at the local level is indeed not a single phenomenon separated from the governance. It is rather a series of phenomena of central and regional governments' political policies to create a more democratic social life. The Authors understand, the desire of the state to interfere in political policy-making aims to create national political stability. The Authors elaborate on the concept of "recognition" to explore the effects of habitus, doxa, social capital, and political arena in Nagari. It means, there must be understanding and commitment among local elites in Nagari and the elite at the central level in formulating the political power at the lowest level i.e. at Nagari/village.

\section{References}

[1] Bourdieu, P. (1986). Social Space and Symbolic Power. Translation. LoicWacquant. Sociological Theory. Vol 7. No.1 Spring 1989.

[2] Bourdieu, P. (1990). The Logic of Practice.Translation by Richard Nice. California: Stanford University Press.

[3] Von Benda, Keebet\& Benda-Beckmann. (2000). GoyahnyaTanggaMenujuMufakat: PeradilanNagaridanPengadilanNegeri di Minangkabau. Translation. Jakarta: Grasindo.

[4] Denzin, Norman K. and Yvonna S. Lincoln. (2009). Hand book of qualitative research. (trans.), Yogyakarta: Pustaka Pelajar 